\title{
Federal Enforcement of Migrant Workers' Labour Rights in Canada: A Research Report
}

Eric M Tucker

Osgoode Hall Law School of York University, etucker@osgoode.yorku.ca

Sarah Marsden

Faculty of Law, Thompson Rivers University

Leah F. Vosko

York University

Source Publication:

Pre-Print

Follow this and additional works at: https://digitalcommons.osgoode.yorku.ca/scholarly_works

Part of the Labor and Employment Law Commons

\section{Repository Citation}

Tucker, Eric M; Marsden, Sarah; and Vosko, Leah F., "Federal Enforcement of Migrant Workers' Labour Rights in Canada: A Research Report" (2020). Articles \& Book Chapters. 2795.

https://digitalcommons.osgoode.yorku.ca/scholarly_works/2795

This Article is brought to you for free and open access by the Faculty Scholarship at Osgoode Digital Commons. It has been accepted for inclusion in Articles \& Book Chapters by an authorized administrator of Osgoode Digital Commons. 


\title{
Federal Enforcement of Migrant Workers' Labour Rights in Canada: A Research Report
}

\author{
Sarah Marsden \\ Faculty of Law, Thompson Rivers University
}

\begin{abstract}
Eric Tucker
Osgoode Hall Law School, York University; Distinguished Scholar in Residence, Cleveland Marshall College of Law, Cleveland State University
\end{abstract}

\author{
Leah Vosko \\ Political Science, York University*
}

\begin{abstract}
Although Canada's migrant labour program is seen by some as a model of best practices, rights shortfalls and exploitation of workers are well documented. Through migration policy, federal authorities determine who can hire migrant workers, and the conditions under which they are employed, through the provision of work permits. Despite its authority over work permits, the federal government has historically had little to do with the regulation of working conditions. In 2015, the federal government introduced a new regulatory enforcement system - unique internationally for its attempt to enforce migrants' workplace rights through federal migration policy - under which employers must comply with contractual employment terms, uphold provincial workplace standards, and make efforts to maintain a workplace free of abuse. Drawing on enforcement data, and frontline law and policy documents, we critically assess the new enforcement system, concluding that it holds both promise and peril for migrant workers.
\end{abstract}

* Authorship is listed alphabetically to reflect equal contribution. 
Canada is home to a longstanding and expansive temporary migrant worker program. Migrant workers ${ }^{1}$ in Canada provide essential labour in response to "labour shortages," including in key occupations and sectors unattractive to native-born workers and permanent residents on the terms and conditions employers offer. As observed by Sharma, the concept of "labour shortage" is qualitative: the demand is not for labour generally, but specifically for labour in conditions and for rates of pay that Canadian citizens and permanent residents will not accept. ${ }^{2}$ Industries with a high proportion of migrant workers include agriculture, caregiving and domestic work, retail, and construction.

Canada's federal government regulates migrant labour through immigration law and policy, under which state authorities determine who can hire migrant workers, and the conditions under which they may be employed, by way of granting permission to employers to hire migrant workers and granting work permits to the workers themselves.

Elements of Canada's migrant work programs are often touted as "best practice" examples. ${ }^{3}$ Yet worker exploitation and rights shortfalls are well documented within various components of Canada's migrant labour programs. Evidence suggests that exploitation is most acute among those engaged in low-skilled jobs, tied partly to the dirty, dangerous, and demeaning work they perform (e.g., agricultural workers and caregivers). ${ }^{4}$ Some such exploitive practices violate applicable legislated minimum standards that are primarily regulated by provincial/territorial law. These include employment standards (e.g., minimum wage, overtime etc.), occupational health and safety regulation (e.g., the provision of proper safety equipment), and human rights (e.g., non-discrimination on the basis of gender, race/ethnicity). Other rights shortfalls arise from a failure to fulfil the terms attached to the closed work permit (e.g., the work not being performed for the employer specified, the work being of a different nature than that described in the initial job offer). These shortfalls are amplified by the limited labour

\footnotetext{
${ }^{1}$ In what follows, we use the term "migrant worker" to refer in general to workers in Canada without permanent residency status. In principle, this group includes undocumented workers, but because our study is focused on documented workers, the term has this more limited meaning herein. Documented migrant workers enter Canada under two programs: the Temporary Foreign Worker Program (TFWP) and the International Mobility Program (IMP). We refer to workers in the TFWP as TFWs. All TFWs fall within the inspection program. Only some workers migrating under the IMP (those requiring closed work permits) fall within the ambit of the program. Our focus is TFWs but, where appropriate, we indicate when we are also referring to covered IMP workers.

2 NANDita Sharma, Home Economics: NATIONAlism AND the Making OF "Migrant Workers" in CANADA 133 (2006).

${ }^{3}$ Hennebry, Jenna L., and Kerry Preibisch. "A model for managed migration? Re-examining best practices in Canada's seasonal agricultural worker program." International Migration 50 (2012): e19-e40. ${ }^{4}$ See Sedef Arat-Koc, 'Good Enough to Work but Not Good Enough to Stay': Foreign Domestic Workers and the Law, in LOCATING LAW: RACE/CLASS/GENDER CONNECTIONS 125, (Elizabeth Comack ed., 1999); Tanya Basok, Free to Be Unfree: Mexican Guest Workers in Canada, 32 LAB. CAP. \& Soc'Y 192, (1999); Jenna Hennebry, Permanently Temporary? Agricultural Migrant Workers and Their Integration in Canada, 26 INST. FOR RES. ON PUB. POL'Y (2012), https://irpp.org/wp-content/uploads/assets/research/diversityimmigration-and-integration/permanently-temporary/IRPP-Study-no26.pdf; Kerry Preibisch, Pick-YourOwn Labor: Migrant Workers and Flexibility in Canadian Agriculture, 44 INT'L MIGRATION REV. 404, (2010).
} 
mobility and deportability of temporary foreign workers (TFWs), conditions that create structures of vulnerability and unfreedom and make voicing complaints particularly risky. ${ }^{5}$

Despite evidence of these challenges and the manner in which legal and policy structures serve to entrench migrant worker vulnerability, the federal government has historically had little to do with the regulation of working conditions for migrant workers. Rather, employment standards, occupational health and safety, and human rights fall largely within provincial/territorial authority. Migrant workers are covered by these laws, but their deportability, limited labour mobility, and the prevalence of complaint-based systems for redress tend to limit their enforcement. So, while the federal immigration system created structures of vulnerability, historically the government has disclaimed responsibility for addressing the resulting labour rights violations and instead exercised its powers solely to protect Canadian jobs and the domestic labour market. ${ }^{6}$

The government's refusal to exercise its powers for the protection of migrant workers began to change in 2011 with the introduction of a very limited employer compliance review process. However, it was only in 2015 that the federal government created an enforcement regime that, for the first time, required employers to comply with basic labour standards and the terms of migrant workers' contracts as a condition of hiring migrant workers.

Like Canada's labour migration program, the federal enforcement system may come to be considered externally, including by other states, as a model policy for protecting migrant workers. With this in mind, we provide the first analysis of this new system. We draw on program statistics, federal enforcement data and operational policy materials we obtained through freedom of information requests, alongside legislation, regulations, and case law to provide a comprehensive view of the regulatory structure and the policy by which frontline officers interpret and apply the new system. We evaluate the federal enforcement system, taking into account an extensive enforcement literature on the efficacy of different styles of regulatory enforcement systems for securing meaningful employer compliance with labour standards, as well as the particular vulnerabilities that result from migrant workers' precarious immigration status. We conclude that the extreme compliance orientation and practice of federal enforcement, in conjunction with other design flaws, undermine the protective potential of the new system.

\footnotetext{
${ }^{5}$ On the migrant workers' condition of unfreedom, see Todd Gordon, Capitalism, Neoliberalism, and Unfree Labour, CRITICAL SOC. (2018); ROBERT MILES, CAPITALISM AND UNFREE LABOUR: ANOMALY OR NECESSITY (1987).

${ }^{6}$ Bridget Anderson, Migration, Immigration Controls and the Fashioning of Precarious Workers, 24 WoRK EMP. AND Soc'Y. 300 (2010); Mimi Zou, The Legal Construction of Hyper-Dependence and HyperPrecarity in Migrant Work Relations, 31 INT'L J. COMP. LAB. \& INDUS. REL. 141 (2015); Chris F. Wright et al., Employer-Sponsored Temporary Labour Migration Schemes in Australia, Canada and Sweden: Enhancing Efficiency, Compromising Fairness?, 43 J. ETHNIC \& MIGRATION STUD. 1185 (2017).
} 


\section{The Significance of Temporary Migration in Canada: Patterns and Trends}

As within the OECD overall, Canada's migration policy has seen a movement away from the post-World War II orientation of permanent immigration towards temporary migration for employment. ${ }^{7}$ Indeed, from 2009 to the present, total temporary migration for employment grew steadily, with the number of temporary work permits for work purposes (i.e., excluding refugees and people awaiting permanent status) exceeding admissions to permanent residency for economic reasons. ${ }^{8}$ Just over 300,000 $(302,821)$ temporary migrant workers signed permits in 2017 (up from 116,540 in 2000), but Canada granted permanent status to just 159,262 (economic class) immigrants that year (up from 136,287 in 2000); temporary migrants thus went from representing $46 \%$ to $66 \%$ of total economic migrants between 2000 and $2017 .^{9}$

Non-residents wishing to work in Canada are required to obtain work permits that fall into two broad categories (see Figure 1 below). In the first category, permits are issued under the Temporary Foreign Worker Program (TFWP). These permits cover positions for which a Labour Market Impact Assessment (LMIA) is required. All of these permits limit the worker to working for a specific employer, for a specified time period, in a named role. They are often described as "closed" or "bonded" work permits, as the worker is not authorized to work in any other position, or for any other employer, than those listed on their permit. These permits are potentially available to any employer and for any type of work, provided the employer can meet a labour market test. Historically, however, the largest groups of workers have been in agricultural and domestic work pursuant to specific sub-programs of the TFWP. ${ }^{10}$ In order to change employers, the prospective new employer must obtain another LMIA, which is an employer-initiated

\footnotetext{
7 ORganisation FOR ECONOMIC Co-OPERATION AND DEVELOPMENT, INTERNATIONAL MIGRATION OUTLOOK 2018 25-7 (2018); see also Salimah Valiani, The Shifting Landscape of Contemporary Canadian Immigration Policy: The Rise of Temporary Migration and Employer-Driven Immigration, in PRODUCING and Negotiating Non-CitizenshiP: Precarious Legal Status in CANAdA 55 (Luin Goldring \& Patricia Landolt eds., 2013).

8 ImmigRation, Refugees and Citizenship CANADA, FACTS AND FiguREs 2016: IMmigRATION OVERVIEW PERMANENT RESIDENTS (2016), http://www.cic.gc.ca/opendata-donneesouvertes/data/Facts_and_Figures_ 2016_PR_EN.pdf; IMMIGRATION, REFUGEES AND CITIZENSHIP , CANADA, 2018 ANNUAL REPORT TO PARLIAMENT ON IMMIGRATION (2018),

https://www.canada.ca/content/dam/ircc/migration/ircc/english/pdf/pub/annual-report-2018.pdf (On an annual basis, Canada admits tens of thousands of immigrants as permanent residents under family and humanitarian classes. However, the majority of permanent residents arriving annually enter under the 'Economic Class'. These migrants receive permanent residency on such bases as their skill level, occupation, and/or financial investments. Permanent residents migrating on economic grounds are nevertheless being outpaced by those on temporary work permits).

${ }^{9}$ See infra Figure 1; LEAH F. VOSKO, DISRUPTING DEPORTABILITY: TRANSNATIONAL WORKERS ORGANIZE tbl.A.3. (Ithaca: Cornell University Press, 2019).

10 One stream within the TFWP is designed specifically for caregivers who, unlike other workers in this stream, are given a pathway to permanent residency. Recently, the government announced it planned to provide caregivers with sectoral rather than employer specific permits. IMMIGRATION, REFUGEES AND Citizenship CanAdA, News Release: Caregivers Will Now Have Access to New Pathways to Permanent Residence (Feb. 23, 2019), https://www.canada.ca/en/immigration-refugeescitizenship/news/2019/02/caregivers-will-now-have-access-to-new-pathways-to-permanentresidence.html
} 
process, beyond the control of the worker. These workers are covered by the new enforcement system under the jurisdiction of ESDC that forms the focus of our study. ${ }^{11}$

The second broad category of temporary work permits fall within the International Mobility Program (IMP), which is comprised of those entering Canada pursuant to international agreements, working holidaymakers, spouses of high-skilled workers, and post-graduates work permit holders, among other groups. Unlike the TFWP, employers do not need to obtain an LMIA in order to hire a worker under the IMP. Most migrant workers entering under IMP sub-programs that have open work permits and are not subject to an inspection system. However, approximately one-third of those participating in the IMP hold closed work permits, tied to a single employer, a specific occupation, and a location. ${ }^{12}$ This group is subject to an inspection system parallel to that covering the TFWP, but enforced by IRCC rather than ESDC. ${ }^{13}$

\section{Figure 1: Canada's Migrant Worker Programs: Labour Market Tests and Types of Work Permits}

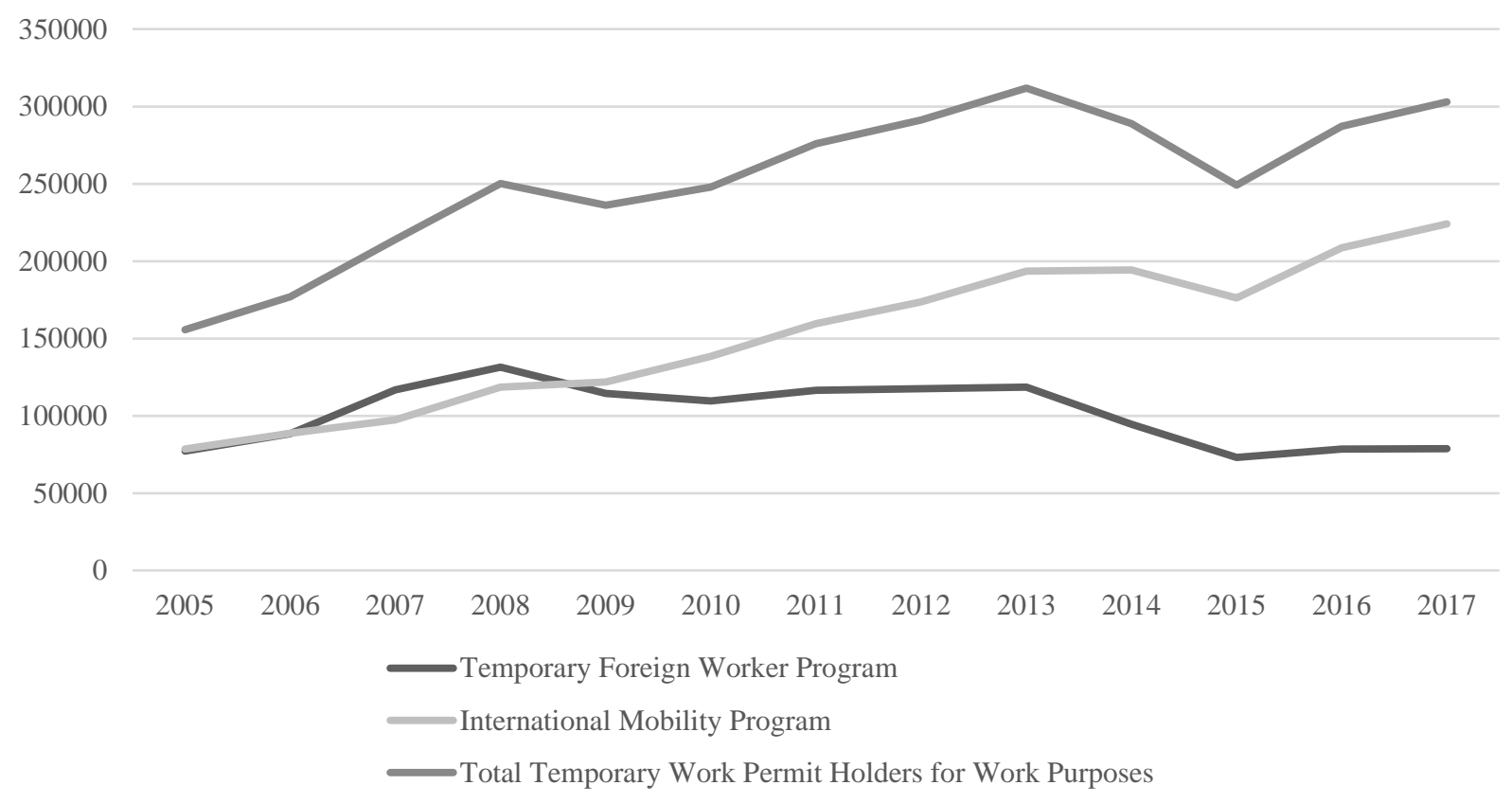

\footnotetext{
${ }^{11}$ Employment and Social Development Canada, previously known as Human Resources and Skills Development Canada

12 Regulations Amending the Immigration and Refugee Protection Regulations: Regulatory Impact Analysis Statement, 152 CAN. GAZETTE 2 (2018), http://www.gazette.gc.ca/rp-pr/p1/2018/2018-1215/html/reg1-eng.html.

${ }^{13}$ Immigration and Refugee Protection Regulations, SOR 2002-227 § 209.2(1) (Can.) [hereinafter IRPR]. IRCC was formerly known as Citizenship and Immigration Canada ("CIC").
} 
Figure 2: Temporary Work Permit Holders for Work Purposes*, 2005-2017

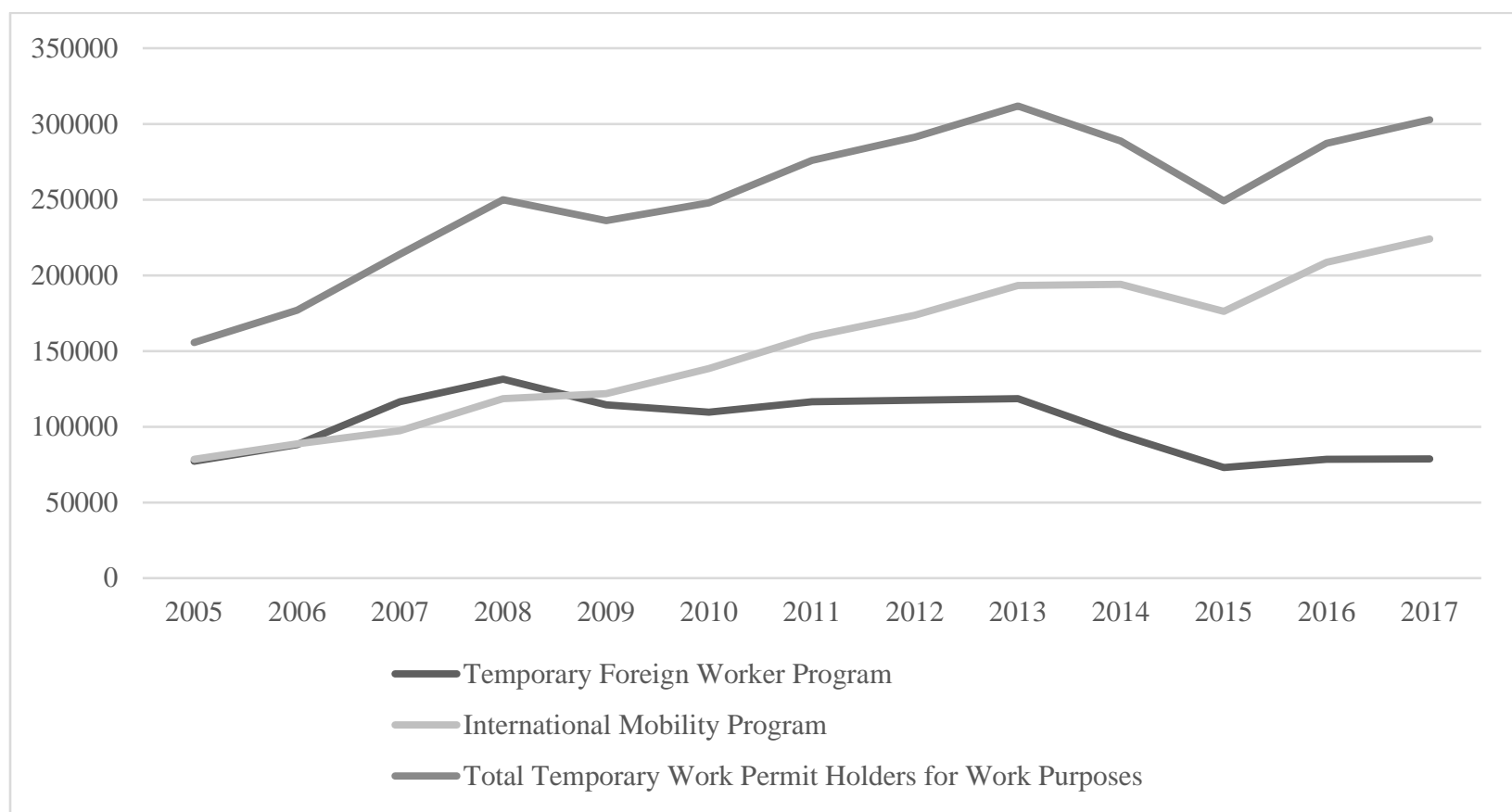

The total number of IMP participants almost tripled between 2005 and 2017 whereas the number of TFWP participants declined precipitously from 2013 to 2017, after stabilizing at high levels between 2007 to 2013 (Figure 2).

Despite the growth of the IMP, TFWs, and the inspection system that governs their employment, are the principal focus here given the magnitude of evidence of the vulnerability of TFWs and also that a highly precarious subset (i.e., those in agriculture) is growing. ${ }^{14}$ On the other hand, migrant workers participating in the IMP are a heterogeneous group, with different degrees of vulnerability that are difficult to document. ${ }^{15}$

\section{The Federal Enforcement System}

\section{Sources of Labour Rights for Migrant Workers: Connecting Federal Immigration Powers to Provincial/Territorial Jurisdiction over Protective Standards}

\footnotetext{
14 Leah Vosko, Eric Tucker and Rebecca Casey, "Enforcing Employment Standards for Migrant Agricultural Workers in Ontario, Canada: Exposing Underexplored Layers of Vulnerability" 35 International Journal of Comparative Labour Law and Industrial Relations 227 (2019); Vosko, surpa. note 9.

${ }^{15}$ For a preliminary discussion and case study of one group of IMPs, see Eric Tucker, Migrant Workers and Fissured Workforces: CS Wind and the Dilemmas of Organizing Intra-Company Transfers in Canada, ECON. \& INDUS. DEMOCRACY (2017), http://dx.doi.org/10.1177\%2F0143831X17707822.
} 
The new enforcement system takes its place in the context of multiple, sometimes overlapping, sources of workplace rights for migrant workers, shaped in part by the division of powers in Canada's federalist system. Under the Canadian constitution, the federal government exercises paramount jurisdiction over immigration. ${ }^{16}$ Labour and employment law is largely a matter of provincial or territorial jurisdiction, and applies to the overwhelming majority of migrant workers, although there are significant barriers to meaningful protection for migrant workers under these laws. ${ }^{17}$ Paramount federal jurisdiction over immigration does not empower the federal government to override provincial or territorial jurisdiction over labour and employment. However, the federal government's immigration jurisdiction does allow it to set conditions for employers who hire migrant workers that must be included in an offer of employment. These terms may be more generous than minimum standards established by applicable workplace laws but may not be lower. Immigration law thus provides migrant workers with a further source of workplace rights, which was underutilized until the implementation of the new enforcement system.

Two federal agencies are directly involved in regulating migrant labour: ESDC, and IRCC. ESDC provides permission to employers to hire migrant workers through Labour Market Impact Assessments (LMIA). To obtain an LMIA, the employer must show that hiring a migrant worker will have a neutral or positive impact on the Canadian labour market. ${ }^{18}$ In making this determination, ESDC officers must consider whether or not:

- there is a labour shortage

- hiring the migrant worker will create or maintain jobs or skills transfer for Canadians and permanent residents

- the wage is consistent with the "prevailing wage" for that job. ${ }^{19}$

\footnotetext{
16 The Constitution Act, 1867 (UK), 30 \& 31 Victoria, c 3, s. 95. Provincial governments have recently assumed a more active role in the selection of immigrants, but not in the enforcement of immigration regulations. For a discussion, see Mireille Paquet, The Federalization of Immigration and Integration in Canada, 47 Canadian Journal of Political Science (2014) and Sasha Baglay and Delphine Nakache, "Immigration Federalism in Canada: Provincial and Territorial Nominee Programs (PTNPs) in Baglay and Nakache, eds., Immigration Regulation in Federal States, (Netherlands: Springer, 2014), 95-116. While limitations of space and scope inhibit us from providing an analysis of the relationship between Indigenous sovereignty and Canadian law here, it nevertheless bears mentioning that Canadian immigration law was developed as a fundamental component of territorial and cultural colonization. Like much of Canada's legal system, its development is linked to the dispossession, murder, violence, and forced assimilation of Indigenous peoples. Indigenous legal systems exist throughout the territory claimed by Canada, and serious questions exist as to the legitimacy of the Canadian state to exert control over this territory, particularly in those parts neither ceded nor subject to treaty; see, e.g., Amar Bhatia, We Are All Here to Stay: Indigeneity, Migration, and Decolonizing the Treaty Right to Be Here, 31 WINDSOR YEARBOOK ACCESS JUST. (2013); Soma Chatterjee, Immigration, Anti-Racism, and Indigenous Self-Determination: Towards a Comprehensive Analysis of the Contemporary Settler Colonial, Soc. IDENTITIES 1 (2018); Laura Madokoro, On Future Research Directions: Temporality and Permanency in the Study of Migration and Settler Colonialism in Canada, 17 HIST. COMPASS (2019).

${ }^{17}$ Federal jurisdiction over labour and employment is limited to only $6-10 \%$ of Canada's private sector labour force and few migrant workers are employed in the federally regulated sector.

18 IRPR, supra note 13, § 203.

19 Id. § 203(3)(d).
} 
Once an employer obtains a positive LMIA, it may make an offer of employment to a migrant worker, who may then apply for a work permit from IRCC. The offer of employment must describe the job duties, rate of pay, and working conditions, as approved in the LMIA. An employer's failure to provide wages and working conditions that are substantially the same as - but not less favourable than - those laid out in the offer constitutes non-compliance with the employers' obligations under immigration law.

Until recently, the federal power to regulate the employers of migrant workers was used solely for protectionist purposes to impose conditions restricting the employment of migrant workers, and not for protective purposes to prevent or remediate abusive treatment of migrant workers. The new system requires employers not only to meet the terms of LMIAs, but also to comply with applicable workplace laws, and make reasonable efforts to provide an abuse free workplace. The latter two obligations created new federally enforceable workplace rights not previously found in LMIAs. ${ }^{20}$

Beyond the use of regulations, it bears mentioning that the federal government has also created workplace rights for a subset of migrant workers through bilateral agreements regulating the longstanding Seasonal Agricultural Worker Program (SAWP) and providing for employment contracts which must meet minimum provincial standards. These contracts per se do not form part of the enforcement system under study, nor are they subject to its inspection powers, but agricultural workers are covered by the new enforcement system as a subset of migrant workers under the overall TFW program to which the new system applies.

To summarize, TFWs have several overlapping sources of labour rights:

- Labour and Employment Law

o Provincial/Territorial labour and employment laws including both statutory and judge-made (common) law (or the federal government's laws for those employed in the federal jurisdiction)

- Immigration Law (federal)

o The terms of the positive LMIA and offer of employment, which may not be inferior to legislated employment standards;

o The right to have their employer make reasonable efforts to provide an abuse-free workplace (from the IRPR);

o For SAWPs, the standard contract arising from interstate agreements and MOUs, which may add to, but may not derogate from, legislated minimum standards.

This brings us to the question of enforcement. In Canada's federalist arrangement, provinces/territories have exclusive jurisdiction over the enforcement of their laws. That labour standards apply to TFWs does not give federal officials authority to enforce them directly. However, because immigration regulations now require employers to comply

${ }^{20}$ IRPR, supra note 13, § 209.3(1)(a)(v). 
with provincial standards, in principle ESDC has the power to treat the violation of provincial standards as immigration law violations and take enforcement action. In contrast, when LMIAs and interstate agreements create labour rights above the statutory floor, provincial officials cannot enforce them; they are only enforceable by immigration officials and/or in court.

As noted, notwithstanding its immigration powers, Canada's federal government has long shirked responsibility for enforcing workplace standards with regard to migrant workers. However, against the backdrop of a series of reports of employer abuse, in the 2010s enforcement initiatives took shape at this level. Indeed, in 2011 law and policy changed to grant ESDC and IRCC the power to actively review employers of migrant workers. This change led to the introduction of paper-based Employer Compliance Reviews (ECRs) that resulted in few employers facing sanctions. In 2015, the federal government implemented a further set of regulatory changes, creating much broader enforcement and inspection powers for ESDC in its role as the first gatekeeper of the TFWP. ${ }^{21}$ This enforcement system is the central object of this analysis.

While our inquiry is concerned primarily with the enforcement of labour rights, or the protective role, this system also enforces the terms of LMIAs that restrict migrant workers' labour market freedom so that they can only be employed in the same occupational category, location and business for which their employer received an LMIA. The scheme is thus designed both to enforce the protectionist restrictions that construct migrant workers' juridical unfreedom and the protective standards that aim to shield migrant workers from the labour rights violations and workplace abuse that they experience disproportionately because of their unfree status. ${ }^{22}$ In the next section, we examine in detail the powers and procedures under the new enforcement system, followed by an analysis of its frontline application in terms of its potential to provide protection to workers.

\section{Powers and Procedures under the New Federal Enforcement System}

The 2015 amendments to the IRPR created new inspection and enforcement powers to regulate the employers of a large number of migrant workers. Here, we discuss how inspections are triggered, the scope of investigative powers, employer justifications and employer sanctions. We then examine the policy that guides the frontline application of these new powers and the case law that defines the scope of protection. Finally, we engage in a critical assessment of the inspection system.

Inspection Triggers

\footnotetext{
${ }^{21}$ A parallel enforcement system by the IRCC was created to enforce the closed work permits and workplace rights of workers in the IMP with closed work permits.

22 See Gordon, supra. note 5 and MILES, supra. note 5.
} 
Federal inspections under the new system may be triggered in three circumstances: a) where an officer has "reason to suspect" that the employer has not complied with the conditions described above; ${ }^{23} \mathrm{~b}$ ) where the employer has not complied with those conditions in the past; and c) as part of a random verification of compliance. ${ }^{24}$ ESDC's policy manual on inspections (henceforth "the Inspections manual") elaborates on these. With regard to "reason to suspect", the manual lists multiple sources of information, including tips from the public (ESDC operates a "tip line"), other federal sources, non-governmental organizations (including unions), provincial/territorial government agencies, and the media. ${ }^{25}$

ESDC reviews all intelligence on the basis of relevance, credibility, and impact and assigns an intelligence score, or "I-score." In the case of known past non-compliance, the Inspections manual indicates that an employer may be selected for inspection at the discretion of staff and based on the nature and severity of the infraction. Random selection is generated using an algorithm whose model aims to provide representative samples and sorting by region, sector, and occupational type. ${ }^{26}$

\section{Investigators' Powers and Duties and Employer Justifications}

Once an inspection is triggered, the new regulations empower officers (in the case of ESDC, Integrity Services Investigators, henceforth "investigators") to exercise broad powers to gather information, in contrast to the previous compliance system, which was narrow, paper-based and focused primarily on information provided by the employer. However, under the new system, an inspection does not require an onsite investigation. To the contrary, the Inspections manual makes it clear that an onsite visit is optional. ${ }^{27}$ The manual specifies when an onsite inspection is required (to ensure worker safety; to verify conditions if required, and to limit employer misrepresentation ${ }^{28}$ and implies that the investigator will consult with the Team Leader prior to determining that one is required. ${ }^{29}$ Although the regulations themselves allow for extensive onsite inspections, paper-based inspections remain implicitly framed as the norm, and onsite inspections the exception. Maintaining the centrality of paper-based inspections represents an under-utilization of the enforcement potential of the new regulations, and signals a compliance orientation at the frontline policy level.

The Inspections manual articulates a set of principles to guide the conduct of inspections. The first principle is that investigators are to "[b]e remedial, rather than adversarial: work with employers during the inspection to educate them about their

${ }^{23} / d$. § 209.3(1).

24 Id. § 209.5.

${ }^{25}$ ECONOMIC AND SOCIAL DEVELOPMENT CANADA, INTEGRITY OPERATIONS MANUAL: CHAPTER 63B TEMPORARY FOREIGN WORKER PROGRAM - INSPECTIONS, § 9.1 (2018) [hereinafter INSPECTIONS MANUAL] (provided in response to a request under the Access to Information Act).

26 ld. § 9.1-3.

27 Id. § 11.8 .

28 Id.

${ }^{29}$ Id. § 11.9 . 
responsibilities under the IRPR and assist them to comply with TFWP conditions." 30 Other principles involve transparency, being unbiased and applying the "precautionary principle" to prevent causing avoidable harm and the "newspaper test" to establish whether an enforcement action, if publicized, would be judged ethical.

To support an onsite or paper-based inspection, investigators can compel employers to provide documentation and to report for questioning. Without a warrant, they can enter workplaces (for private residences, warrants are required), examine anything on the premises, make recordings, and require employers to show electronic records. ${ }^{31}$ The requirement to comply with investigators is imposed on all employers as a condition of hiring migrant workers, ${ }^{32}$ and the employer bears the burden of proof to show that it is compliant. ${ }^{33}$

On finding that an employer has breached the regulatory conditions, the investigator must provide a "notice of preliminary finding" to the employer, to which the employer has 30 days to respond, for example, by contesting the alleged facts or providing a justification for the breach. ${ }^{34}$ The regulation lists seven acceptable justifications. These include a change in federal or provincial law; an error in interpretation made in good faith (with compensation); an unintentional accounting or administrative error (with compensation); and force majeure..$^{35}$ If the employer does not provide an acceptable justification, the employer is non-compliant and liable to sanctions. Despite the generality of these justifications, in Obeid Farms, the Federal Court held:

[T]he justification provisions must be strictly interpreted. The intention of Parliament in enacting these provisions was to prevent abuse of highly vulnerable temporary foreign workers, given the tenuous circumstances of their employment which lack the normal safeguards preventing abuse otherwise available to most Canadian workers. ${ }^{36}$

Below, we examine how strictly investigators interpret these justifications in the field in terms of inspections and outcomes. ${ }^{37}$

$30 / d . \S 5$.

31 IRPR, supra note 13, §§ 209.6-209.9.

32 Id. § 209.4.

33 INSPECTIONS MANUAL, supra note 25, § 11.10.

34 Id. § 15; IRPR, supra note 13, §§ 209.993-209.994.

35 IRPR, supra note 13, §§ 209.3(3), 203(1.1).

36 Obeid Farms v. Canada (Minister of Employment and Social Development), [2017] F.C. 302, para. 31 (Can.).

37 It bears noting that the Inspections Manual provides that where an investigator has accepted a justification from a noncompliant employer, a similar justification in similar circumstances should generally not be accepted a second time, unless the employer can show "legitimate reasons" for so doing; see INSPECTIONS MANUAL, supra note 25, § 6. 


\section{Types of Outcomes and Penalties}

Inspection outcomes are classified as either "satisfactory," "satisfactory with justification," "satisfactory with justification and compensation," or "non-compliant." 38 If the investigator is satisfied that the breach occurred and was not justified, the investigator is to document the situation and make a recommendation to the program area. ${ }^{39}$ An official in the program area will make the final decision and, if they agree with the investigator's recommendation, the area officer will issue a notice of final determination, including any monetary penalties and a ban on hiring migrant workers, if applicable.

Penalties are calculated according to a formula set out in the regulations, which accounts for frequency and severity of violations and represents the employer's noncompliance as a number of points. It is possible in this system for an employer to receive only 0 or 1 point, in which case a warning will be issued. Two or more points will result in a monetary penalty, publication of the employer's name on a website hosted by IRCC listing noncompliant employers, and the employer may also be banned from hiring migrant workers temporarily or permanently. ${ }^{40}$

This approach to punishment draws on principles and practices common in other licensing regimes, such as drivers' licenses or, in the United Kingdom, gangmasters' licenses, in which the accumulation of points can eventually result in the loss of the license. ${ }^{41}$ The adoption of this approach is not surprising since, as we noted above, the LMIA regime effectively operates as a licensing scheme for employers wishing to hire migrant workers in the TFWP that provides employers with permission to hire TFWs under specified conditions.

Unlike most other labour inspection regimes in Canada (i.e., provincially, territorially, and in the federally-regulated private sector), investigators cannot issue compliance orders. One would, therefore, expect that a finding of non-compliance would result in employer penalties. However, indicative of a deeply compliance-oriented model of enforcement, the Inspections manual states that investigators should instead work with employers to bring them into compliance rather taking a deterrent approach. ${ }^{42} \mathrm{It}$ provides that in addition to "conducting investigations" and "validating compliance", the investigator "[d]etermines non-compliance and identifies corrective measures" and "[w]orks with employers in [an] effort [sic] to achieve compliance when non-compliance was determined" 43 In short, in the absence of a power to issue compliance orders, the

\footnotetext{
38 Employment ANd Social DeVElopment CANAdA, Policy: Employer InSPECTION ANd Determination of CONSEQUENCES, 20 (2018) [hereinafter CONSEQUENCES GUIDELINE] (provided in response to a request under the Access to Information Act); INSPECTIONS MANUAL, supra note 25, § 12.

39 INSPECTIONS MANUAL, supra note 25, § 12.

40 ld. $\S \S 209.98$ - 209.997, sched. 2; CONSEQUENCES GUIDELINE, supra note 38 at 26.

${ }^{41}$ Catherine Barnard, Amy Ludlow \& Sarah Fraser Butlin, Beyond Employment Tribunals: Enforcement of Employment Rights by EU-8 Migrant Workers, 47 INDUS. L.J. 226 (2018).

42 Id. § 8 .

43 Id. at 17.
} 
manual directs investigators to negotiate compliance as a first response to a finding of non-compliance. As we demonstrate below, penalties are rarely imposed.

\section{Frontline Policy Directions Regarding Protective Labour Rights}

As noted above, the federal enforcement system includes three protective obligations: compliance with the terms of the offer of employment; compliance with applicable labour and recruitment laws; and, the duty to take reasonable steps to provide an abuse-free workplace. Before turning to the practice of enforcement, however, we highlight a few key directions that govern inspection practices.

\section{Non-Compliance with the Offer of Employment}

Offers of employment must describe the job duties and stipulate wages and other working conditions such as hours of work. Employers cannot provide pay or working conditions less favourable than those set out in the offer, LMIA letter, and annexes. ${ }^{44}$ According to policy, employers cannot substitute one condition for another. For example, the employer cannot substitute increased compensation for health insurance if the job offer/LMIA included a requirement to provide health insurance. Where noncompliance is detected, employers may offer any of the justifications permitted in the regulations. ${ }^{45}$

The manual contains specific instructions for inspections of workplaces employing migrant agricultural workers, whose rights are governed in large part by the federal National Commodities list and a standard form contract. Notably, inspectors are directed to defer to housing inspectors with regard to onsite worker housing, and not to assess pesticide use directly, relying instead on employers' paperwork. ${ }^{46}$

\section{Compliance with Applicable Federal and Provincial/Territorial Laws}

The Inspections manual lists examples of the laws covered by this obligation, including employment standards, workers' compensation, occupational health and safety, and laws designed to protect foreign nationals. The list does not include collective bargaining or human rights laws, both of which clearly apply to, and protect the rights of, employees. ${ }^{47}$ Therefore, these laws should be listed, since they are covered by regulation. The failure to do so may, in practice, result in their being overlooked by inspectors.

\footnotetext{
44 IRPR, supra note 13, § 209.3(1)(iv).

45 Id. § 11.17.iii.

46 INSPECTIONS MANUAL, supra note 25, app. C.

47 INSPECTIONS MANUAL, supra note 25, § 11.17.vi.
} 
This manual makes clear that investigators may consider present and past compliance, going back six years. ${ }^{48}$ Although the employer ostensibly bears the burden of proving compliance, in the absence of proof of non-compliance, the employer will generally be found not in violation. ${ }^{49}$ Moreover, federal inspectors do not independently determine whether an employer has violated workplace law. Rather, they are only to determine whether the employer has been found in violation by the federal/provincial/territorial authority primarily responsible for the law's enforcement. ${ }^{50}$ The federal enforcement system, therefore, does not increase the likelihood that violators will be detected; rather, it creates additional potential liabilities for employers caught violating applicable statutory labour rights. As a result, the enforcement of workplace laws under the inspection system is only as good as those primary enforcement regimes.

\section{Failure to Make Reasonable Efforts to Provide A Workplace Free of Abuse}

The third requirement that pertains directly to working conditions is that employers "make reasonable efforts to provide a workplace that is free of abuse." 51 The regulations define "abuse" as follows:

For the purpose of this Part abuse consists of any of the following:

(a) physical abuse, including assault and forcible confinement;

(b) sexual abuse, including sexual contact without consent;

(c) psychological abuse, including threats and intimidation; and

(d) financial abuse, including fraud and extortion. ${ }^{52}$

The policy manual stipulates that when ESDC "receives information indicating that a TFWP employer or one of their employees have been accused of committing or found to have been convicted of abuse-related crimes, that employer will be Inspected...to determine whether reasonable efforts have been made to provide a workplace free of abuse." ${ }^{33}$ This formulation seems to suggest that the trigger for an inspection is a criminal accusation or conviction. However, the manual later states that "[a]II TFWP related allegations of abuse received by ESDC/FC are reviewed and assessed," and the manual recognizes that investigators may discover that this type of abuse has occurred during a regular inspection. ${ }^{54}$

"Reasonable efforts" is not a defined term in the regulations, but the inspections policy gives a list of criteria to determine whether reasonable efforts have been made, namely:

-The employer had made general efforts to prevent workplace abuse

\footnotetext{
48 Id. § 14.12.

49 Id. § 11.17.vi.

50 ld. § 5.4. Id. § 11.17.vi.

51 IRPR, supra note 13, § 209.3(1)(a)(v).

52 Id. § 196.2.

53 INSPECTIONS MANUAL, supra note 25, § 14.10.

${ }^{54}$ Id. § 14.10.iii.
} 
-The employer, or anyone in a supervisory role or acting on the employer's behalf, has not actively participated in abuse, including failing to stop abuse of which they had knowledge; and -Where an allegation or incident of abuse occurred, steps were taken by the employer to address abuse and prevent it from happening again ${ }^{55}$

As with other sections of the manual, the "elements to assess" section of the policy manual has been redacted. However, the manual does give examples of how an employer could prove compliance with this requirement, including showing their abusefree policies and procedures, demonstrating their efforts to inform and educate employees of the policies and procedures, and demonstrating their ongoing commitment to provide a work environment that is free from abuse and violence. The manual also states that policies may vary, and smaller employers may have no specific policies at all. Nevertheless, all employers "must make efforts to treat employees, including TFWs, in a fair and abuse free manner and to take steps to provide a work environment that is free of abuse and violence" 56 (italics in original).

The manual informs inspectors about what to expect from employers after an actual incident of abuse. In such a case, the employer is required to provide "a high-level description of a process" that includes an assessment of the facts, support measures for the victim, referral of the allegation to the relevant authority, action taken by the employer in response, and follow up. ${ }^{57}$ None of the materials we obtained provide guidance on how to assess employer justification with regard to a finding that it failed to make "reasonable efforts to maintain a workplace free of abuse."

The Consequences guideline suggests a more direct role for investigators where there is an allegation, incident, or reasonable concern that abuse may have occurred. ${ }^{58}$ For example, although investigators do not have authority to inspect workers' bodies, they are directed to look for signs of physical confinement or abuse, such as "bruises, blood, and intimidated workers." 59 In regard to sexual abuse, they should look for signs such as "intimate relations between workers or between workers and management, erotic literature, photographs and/or websites, in the workplace, trafficking in persons...."60 The policy also discusses when the employer will be considered actively responsible for the abuse, including where the employer or its agent has directly abused a worker, where "it is more likely than not" that the employer or its agent directed, encouraged, or supported abuse, where there is evidence that the employer protected the abuser, and where the employer has placed an employee who has been convicted of abuse in contact with a migrant worker. ${ }^{61}$

\footnotetext{
55 INSPECTIONS MANUAL, supra note 25 , § 14.10.i.

56 Id. § 14.10.ii.

57 Id. § 14.10.iv.

58 CONSEQUENCES GUIDELINE, supra note 38, § 5.2.2.

59 ld. at 15.

$60 \mathrm{ld}$.

$61 \mathrm{ld}$. at 16.
} 
Either way, the regulation is concerned with the issue of whether the employer has made "reasonable efforts", not with whether it has succeeded in providing an abuse-free workplace. The requirement for employers to make reasonable efforts to provide a workplace free of abuse has also been considered by the Federal Court in Obeid Farms. ${ }^{62}$ In that case, the Minister found the employer to be non-compliant on multiple grounds, including failing to make reasonable efforts to provide a workplace free of abuse. In reviewing this decision, the Federal Court quashed it with regard to the breach of the "reasonable efforts" requirement. The Federal Court noted that the investigator's report erroneously described the requirement as being "to provide a workplace that is free of abuse," noting that this "is quite different than whether the employer 'made reasonable efforts to provide a workplace that is free of abuse."'63 While the Court rejected the employer's argument that there must be evidence of actual abuse to support a finding of "no reasonable efforts," 64 it also found that here there was no evidence to show the workplace was "not free of abuse," and concluded that the investigator's finding was unsupported for this reason. ${ }^{65}$

It follows that an investigator does not have to make a finding that abuse occurred, it being sufficient that the employer failed to make reasonable efforts to prevent abuse. In the absence of evidence that abuse has occurred, the manual directs investigators to consider various indicators of the employer's preventive efforts. ${ }^{66}$ Yet in Obeid, the court held that if the employer does not have any policies in place, this does not mean that the employer's efforts to provide an abuse free workplace were not reasonable. The court explained:

Reasonableness is a highly, and indeed, almost entirely contextual standard... Evidence of reasonableness often is based on the norms of other persons in similar circumstances... The court's sense is that other small farming TFW employers might have interpreted this provision in a similar fashion, not really knowing what the requirement really entailed other than assuring no abuse was occurring. ${ }^{67}$

We consider the impact of these confusing directions on the enforcement of the "reasonable efforts" requirement below.

\section{The Practice of Enforcement: Inspections and Outcomes}

To examine the practice of enforcement, we obtained statistics from EDSC on inspection and outcomes. Tables 1 and 2 make it clear that when the inspection program started, paper-based reviews were by far the most frequent. Even in 2016-17,

\footnotetext{
62 Obeid Farms, supra note 36.

63 Id. para 54.

64 Id. para 53.

65 Id. para 55.

66 IRPR, supra note 13, §§ 209.2(4), 209.3(4).

67 Obeid Farms, supra note 36, para. 56.
} 
only 111 onsite inspections were completed out of a total of 3666 inspections, or about $3 \%$. Onsite inspections, however, became more frequent in subsequent years. In 2017-18, about 30\% of completed inspections were onsite, while in 2018-19 (part year), around 55\% were onsite.

The shift from paper reviews to onsite inspections has been accompanied by fewer completed inspections annually. In 2016-17, 3666 inspections were completed, but in 2017-18 the number dropped to 2,888 and for 2018-19 only 867 inspections were completed at the end of six months, so that if this trend continues, there will be fewer than 2000 for 2018-2019.

Table 1

ESDC Overall Inspections and Outcomes, 2016-17 to 2018-19

\begin{tabular}{|c|c|c|c|}
\hline \multicolumn{4}{|l|}{ Overall inspections } \\
\hline Inspections & $2016-2017$ & $2017-2018$ & 2018-2019 (September 30, 2018) \\
\hline Inspections underway & 0 & 2,805 & 2,987 \\
\hline $\begin{array}{l}\text { Onsite inspections } \\
\text { underway }\end{array}$ & 0 & 1,297 & 616 \\
\hline Paper reviews underway & 0 & 1,508 & \\
\hline Inspections completed & 3,666 & 2,888 & 867 \\
\hline $\begin{array}{l}\text { Onsite inspections } \\
\text { completed }\end{array}$ & 111 & 851 & 474 \\
\hline Paper reviews completed & 3,438 & 2,037 & \\
\hline Employer correction & 784 & 1,317 & 392 \\
\hline Non-compliant & 1 & 32 & 16 \\
\hline $\begin{array}{l}\text { Non-compliant pending decision (2- } \\
\text { year ban) }\end{array}$ & 0 & 21 & 16 \\
\hline $\begin{array}{l}\text { Non-compliant pending decision } \\
\text { (AMPs and BANs) }\end{array}$ & 0 & 33 & 0 \\
\hline
\end{tabular}

Source: ESDC, Access to Information Request, A-2018-02770

In terms of inspection results, Table 2 divides completed inspections into the four categories of satisfactory, compliant with intervention, non-compliant, and awaiting final adjudication. ESDC considers "compliant with intervention" identical to "satisfactory with justification/restitution" found in the Inspections manual. Therefore, we must assume that investigators who have determined non-compliance to which employers responded with sufficient justification have reported these as satisfactory or satisfactory with justification (compliant with intervention). 
Table 2

ESDC Results from Completed Inspections, On-site and Paper-Based, by Year, 2015-16 to 2017-18

\begin{tabular}{|c|c|c|c|c|c|c|}
\hline \multicolumn{7}{|c|}{ Results from Completed Inspections and Reviews by Year } \\
\hline & \multicolumn{3}{|c|}{ On-site inspections } & \multicolumn{3}{|c|}{ Paper Based Reviews } \\
\hline & $2015-16$ & 2016-17 & 2017-18 & $2015-16$ & 2016-17 & 2017-18 \\
\hline Satisfactory & 0 & 47 & 391 & 731 & 1,884 & 1,031 \\
\hline $\begin{array}{l}\text { Compliant } \\
\text { with } \\
\text { Intervention }\end{array}$ & 2 & 31 & 427 & 1,015 & 1,222 & 890 \\
\hline $\begin{array}{l}\text { Non- } \\
\text { Compliant }\end{array}$ & 0 & 1 & 8 & 140 & 54 & 18 \\
\hline $\begin{array}{l}\text { Awaiting } \\
\text { Final } \\
\text { Adjudication }\end{array}$ & 2 & 32 & 9 & 1,551 & 278 & 94 \\
\hline Total & 4 & 111 & 835 & 3,437 & 3,438 & 2,033 \\
\hline
\end{tabular}

Source: ESDC, Access to Information Request A-2018-02770

Over the three complete years for which we have data (2015-16 to 2017-18), the most frequent outcome was satisfactory (about $40 \%$ ) followed by compliant with intervention (about 36\%), awaiting final adjudication (about 20\%), and non-compliant (about 4\%) (Table 3).

We can also calculate the percentage of employers who were found non-compliant in the first instance by adding together the categories "non-compliant" and "compliant with intervention" and divide that by the number of completed inspections less those awaiting final adjudication. The result is that nearly $50 \%$ of employers were found to be noncompliant in the first instance. However, about $90 \%$ of the employers found to be noncompliant offered a justification (with restitution when required) that was accepted by the investigator. Only $10 \%$ of employers found non-compliant in the first instance were ultimately cited as non-compliant (361 out of 3948) (Table 3). 


\section{Table 3}

\section{Outcomes of Completed Inspections, By Inspection Type and Totals, 2015/16 to}

2017/18

\begin{tabular}{|l|l|l|l|}
\hline & Onsite: Number (\%) & Paper: Number (\%) & Total: Number (\%) \\
\hline Satisfactory & $438(46 \%)$ & $3646(40 \%)$ & $4044(40 \%)$ \\
\hline $\begin{array}{l}\text { Compliant with } \\
\text { Intervention }\end{array}$ & $460(48 \%)$ & $3127(35 \%)$ & $3587(36 \%)$ \\
\hline Non-Compliant & $9(1 \%)$ & $352(4 \%)$ & $361(4 \%)$ \\
\hline Awaiting Adjudication & $43(5 \%)$ & $1923(21 \%)$ & $1966(20 \%)$ \\
\hline & $950(100 \%)$ & $9048(100 \%)$ & $9998(100 \%)$ \\
\hline
\end{tabular}

Source: ESDC, Access to Information Request A-2018-02770 (Calculated from Table 2)

Unfortunately, data are not available on the reasons why employers were found noncompliant in the first instance. This is an important lacuna since it prevents us from determining the extent to which inspections are targeting the protective aspects of the regulations or the protectionist ones. We also do not have data specifying the accepted justifications in cases of initial non-compliance. These too, are important, since their analysis would allow us to better understand how this supposedly narrow exception is being interpreted so that it excuses $90 \%$ of the non-compliance detected in the first instance.

The overall results differ by type of inspection and year. Looking at type of inspection, the most frequent outcome for onsite inspections is compliant with intervention (about $48 \%$ ), followed by satisfactory (46\%), awaiting final adjudication (5\%) and noncompliant (1\%). For paper inspections, the most frequent outcome is satisfactory (about 40\%), compliant with intervention (35\%), awaiting adjudication (21\%) and noncompliant (4\%). In either case, if we leave aside awaiting adjudication, which is an indeterminate outcome, a very small fraction of inspected employers is found to be noncompliant (about 4\%), although that outcome is more frequent for paper than for onsite inspections.

If we look at the data over time, we see that the rate of employers found to be noncompliant (excluding those awaiting adjudication) has been steady at $1 \%$ of those subject to onsite inspections but has varied among those subject to paper inspections (7\% in 2015-16, 17\% in 2016-17 and 9\% in 2017-18).

The Canadian government maintains a public list of non-compliant employers, which as of 17 April 2019 contained 149 names. The list is compiled from both ESDC (TFWs) and IRCC (IMP) inspections and includes employers who were found non-compliant under the ECR review process. Our analysis of IRCC enforcement data from 2015-16 to 2017-18 shows that a total of 17 employers were found non-compliant. Therefore, we can assume that the great majority of employers listed as non-compliant are from ESDC inspections or ECR reviews. The list of non-compliant employers partially illuminates the reasons for the finding of non-compliance. In 53 of the 149 cases, no reason is provided because the non-compliance occurred before the new regulations 
came into force in December, 2015. These 53 employers were found non-compliant under the pre-2015 process. That leaves 96 employers who were found non-compliant on inspection and for whom we have reasons.

In some cases, employers were found to be non-compliant for more than one reason and so the total number of reasons given (122 - Table 4) exceeds the number of noncompliant employers. Table 5 identifies the reasons by year by the numerical key, which corresponds with the relevant section of the regulation. For ease of analysis, we divided these reasons into categories. Administrative reasons include such things as failing to keep or provide an investigator with requested documents or failing to attend a meeting or inspection. LMIA enforcement refers to the enforcement of provisions related to the protectivist requirements such as those related to the job description or related to creating new jobs or improved skills for Canadians. Unfortunately, compliance with LMIA conditions blends protection and protectivist concerns; thus, it is impossible to know whether employers were found non-compliant for a workplace rights violation or for failing to employ the migrant worker in the job described in the LMIA.

The non-compliance list provides several interesting insights. First, the number of employers who were found non-compliant under the enforcement system increased dramatically in 2019 (Table 6). This increase does not mean that more non-compliance has been detected in 2019, however, since 2019 is the year of decision, not the year of violation, and a great many employers (40) were added to the non-compliance list in January of 2019. Thus, we cannot tell whether the increase in 2019 reflects a resolution of some kind of bureaucratic glitch in processing cases or an increase over time in the number of employers being found non-compliant.

In the overwhelming majority of cases where non-compliance is detected in the first instance, the outcome is "compliant with intervention." This finding strongly suggests that investigators are encouraged to secure compliance and to use sanctions only when employers are not cooperative. The prominence of employer justifications in reported outcomes also provides evidence of a compliance orientation. These include good faith errors or unintentional actions where compensation is provided to workers. In addition, where employers have been found non-compliant with regard to administrative obligations, such as record keeping, employers can justify the violation by showing that they made all reasonable efforts to comply. ${ }^{68}$ Investigators imbued with a compliance orientation will likely be open to accepting these kinds of justifications for noncompliance notwithstanding the judicial pronouncement, in Obeid, that justifications should be strictly construed. The ESDC data strongly suggest that justifications are readily accepted - as noted above, $90 \%$ of employers who are found to be noncompliant in the first instance provide justifications deemed acceptable. ${ }^{69}$

\footnotetext{
68 IRPR, supra note 13, §§ 209.2(4), 209.3(4).

69 IRCC inspection data covering the three years from 2015-16 to 2017-18 show that of the 1353 inspections, employers were found compliant "with justification" only $14 \%$ of the time, while only about $1 \%$ were found non-compliant. About $85 \%$ were found to be compliant (IRCC data). The enormous differences between ESDC and IRCC outcomes for compliant and compliant with justification raises a question about how investigators in each scheme are recording inspection outcomes.
} 
With regard to the reasons why employers are found non-compliant, Table 6 shows that nearly half of the reasons given relate to administrative matters (70), the most common by far being the failure to provide the investigator with requested documents.

Violations of the protectionist, restrictive conditions of the LMIA is a reason given in for a finding of non-compliance 11 times, but the number is probably larger if we assume that some proportion of the "working conditions or job description" category relates to noncompliance with the job description. The fact that the most common reason for employers being cited for non-compliance is that they failed to provide the investigator with documents, or some other administrative reason, rather than a substantive labour rights violation further supports the conclusion that the enforcement system is heavily compliance oriented. Non-cooperation with the investigator is the offence that is taken most seriously.

Only one employer has been found non-compliant because of its failure to comply with applicable protective employment laws. This is not a surprising result since, as we noted earlier, federal investigators do not make an independent determination of whether a violation has occurred but depend on the provincial/territorial authorities with primary enforcement jurisdiction and studies have shown that statutory labour rights are poorly enforced generally, and that enforcement for precariously employed workers, and TFWs in particular, is especially fraught. ${ }^{70}$ In effect, then, the federal enforcement system, which was called into existence in large measure because of the failure of primary enforcement to protect migrant workers against rights' violations, has been implemented to make it structurally dependent on the flawed enforcement system it is supposed to ameliorate.

With regard to the duty to make reasonable efforts to provide an abuse-free workplace, no employers are reported here for non-compliance. However, as discussed earlier, while one employer, Obeid Farms, was found to be in violation of this requirement, that finding was overturned by the Federal Court. It is not surprising that in the judgment's aftermath investigators have not cited employers for failing to make reasonable efforts, since the absence of any positive efforts by the employer to prevent abuse does not provide a sufficient basis for finding the employer failed to make reasonable efforts. In effect, the court has made the positive duty to take reasonable efforts unenforceable, and instead transformed the provision into a due diligence defence that an employer can raise if there is a finding that abuse occurred. "But I made reasonable efforts....".

The court implicitly recognized this result and invited the Minister to consider whether it would be advisable to make it clear what proactive measures were expected of employers, but to date no action has been taken. ${ }^{71}$

Finally, we do not know how many employers have been cited for not complying with their duty to provide working conditions at least as favourable as those stipulated in the

\footnotetext{
70 Leah F. Vosko, 'Rights without Remedies': Enforcing Employment Standards in Ontario by Maximizing Voice among Workers in Precarious Jobs, 50 OsGOODE HALL L.J. 845 (2013).

${ }^{71}$ Obeid Farms, supra note 36, para. 59.
} 
LMIA because the category has been melded with the job description issue. The number is somewhere between zero and forty (Table 5).

Table 4

Reasons for Finding of Non-Compliance by Year of Decision and Regulatory Key

\begin{tabular}{|c|c|c|c|c|c|c|c|c|c|c|c|c|c|c|c|c|c|c|}
\hline $\begin{array}{l}\text { Year of } \\
\text { Decision }\end{array}$ & 1 & 2 & 3 & 4 & 5 & 6 & 7 & 8 & 9 & 10 & 11 & 12 & 13 & 14 & 15 & 16 & 17 & $\begin{array}{c}\text { Total } \\
\text { Reasons } \\
\text { Given }\end{array}$ \\
\hline $\begin{array}{c}2019 \text { (to } \\
17.04 \text { ) }\end{array}$ & 4 & 3 & 0 & 1 & 1 & 43 & 0 & 0 & 11 & 0 & 0 & 0 & 0 & 0 & 4 & 0 & 0 & 67 \\
\hline 2018 & 3 & 0 & 0 & 1 & 1 & 7 & 1 & 1 & 12 & 0 & 0 & 0 & 0 & 0 & 4 & 0 & 0 & 30 \\
\hline 2017 & 2 & 1 & 0 & 1 & 0 & 3 & 0 & 0 & 17 & 0 & 0 & 0 & 0 & 0 & 0 & 0 & 0 & 24 \\
\hline 2016 & 0 & 0 & 0 & 0 & 0 & 1 & 0 & 0 & 0 & 0 & 0 & 0 & 0 & 0 & 0 & 0 & 0 & 1 \\
\hline Total & 9 & 4 & 0 & 3 & 2 & 54 & 1 & 1 & 40 & 0 & 0 & 0 & 0 & 0 & 8 & 0 & 0 & 122 \\
\hline
\end{tabular}

Source: Government of Canada, Immigration and Citizenship, "Employers who have been non-compliant" Online at https://www.canada.ca/en/immigration-refugees-citizenship/services/work-canada/employersnon-compliant.html (Accessed 17 April 2019); for an explanation of rows 1017, see Appendix: Regulatory Key.

Table 5

Reasons for Finding of Non-Compliance by Year of Decision and Type of Violation

\begin{tabular}{|c|c|c|c|c|c|c|c|}
\hline $\begin{array}{c}\text { Year of } \\
\text { Decision }\end{array}$ & $\begin{array}{c}\text { Administrative } \\
\text { Reason } \\
(\mathbf{1 , 2 , 5 , 6 , 7 )}\end{array}$ & $\begin{array}{c}\text { LMIA } \\
\text { Enforcement } \\
\mathbf{( 4 , 1 1 , 1 2 , 1 3} \\
\mathbf{1 4 , 1 5 )}\end{array}$ & $\begin{array}{c}\text { Applicable } \\
\text { Workplace } \\
\text { Law (8) }\end{array}$ & $\begin{array}{c}\text { Abuse- } \\
\text { Free } \\
\text { Workplace } \\
\mathbf{( 1 7 )}\end{array}$ & $\begin{array}{c}\text { Working } \\
\text { Conditions } \\
\text { or Job } \\
\text { Description } \\
\mathbf{( 9 )}\end{array}$ & $\begin{array}{c}\text { Live-In- } \\
\text { Caregiver } \\
\mathbf{( 3 , 1 0 , 1 6 )}\end{array}$ & $\begin{array}{c}\text { Total } \\
\text { Reasons } \\
\text { Given }\end{array}$ \\
\hline $\begin{array}{c}\mathbf{2 0 1 9} \text { (to } \\
\mathbf{1 7 . 0 4 )}\end{array}$ & 51 & 5 & 0 & 0 & 11 & 0 & 67 \\
\hline $\mathbf{2 0 1 8}$ & 12 & 5 & 1 & 0 & 12 & 0 & 30 \\
\hline $\mathbf{2 0 1 7}$ & 6 & 1 & 0 & 0 & 17 & 0 & 24 \\
\hline $\mathbf{2 0 1 6}$ & 1 & 0 & 0 & 0 & 0 & 0 & 1 \\
\hline Total & 70 & 11 & 1 & 0 & 40 & 0 & 122 \\
\hline
\end{tabular}

Source: Calculated by authors based on Table 4 
Table 6

Penalties Imposed on Non-Compliant Employers by Year of Decision

\begin{tabular}{|c|c|c|c|c|}
\hline $\begin{array}{c}\text { Year of Final } \\
\text { Decision }\end{array}$ & $\begin{array}{c}\text { Total \# of Non- } \\
\text { Compliant } \\
\text { Employers } \\
\text { (Number Non- } \\
\text { Complaint with } \\
\text { ECR) }\end{array}$ & $\begin{array}{c}\text { Number of } \\
\text { Employers Fined }\end{array}$ & $\begin{array}{c}\text { Number of } \\
\text { Employers } \\
\text { Suspended }\end{array}$ & $\begin{array}{c}\text { Number of } \\
\text { Employers Fined } \\
\text { and Suspended }\end{array}$ \\
\hline $\mathbf{2 0 1 9}$ (to 17.04) & $54(3)$ & 51 & 3 & 0 \\
\hline $\mathbf{2 0 1 8}$ & $47(23)$ & 22 & 24 & 1 \\
\hline $\mathbf{2 0 1 7}$ & $46(26)$ & 19 & 26 & 1 \\
\hline $\mathbf{2 0 1 6}$ & $2(1)$ & 1 & 1 & 2 \\
\hline Total & $149(53)$ & 93 & 54 & 2 \\
\hline
\end{tabular}

Source: Government of Canada, Immigration and Citizenship, "Employers who have been non-compliant" Online at https://www.canada.ca/en/immigration-refugees-citizenship/services/work-canada/employersnon-compliant.html (Accessed 17 April 2019)

In terms of consequences, 54 employers were suspended from the program, in most cases for two years. ${ }^{72}$ Suspensions were more common in the first years of the program, when more than half of non-compliant employers were suspended from the program. Thus far, only three suspensions have been imposed in 2019, suggesting there has been a marked change in approach. When employers are fined, the level of the fine is usually low, in the $\$ 1000$ to $\$ 3000$ range. One company, Kameron Coal in Nova Scotia, was fined $\$ 54,000$ (and received a one-year suspension) but that was truly exceptional. The next highest fine is for $\$ 16,000$, imposed on two companies, Harbour Sushi in BC and Mozza Vera Foods in Quebec. Below these the next highest fines are $\$ 4000$ or less.

A possible reason for the low rate of penalties and citations for non-compliance is that the enforcement system lacks resources to detect non-compliant employers.

Restricting ourselves to TFW inspections by ESDC, there were 3,666 completed paperbased and on-site inspections in 2016/17. ${ }^{73}$ How likely was it that an employer with a TFW would be inspected? Unfortunately, this likelihood is not easy to calculate from the published data. We know that in 2016, about 16,000 employers received positive LMIAs, some for multiple workers. ${ }^{74}$ However, the data do not include employers who use personal names, (e.g., persons who hire caregivers or who use personal names in their business), which eliminates tens of thousands of employers from the list. As well, the data includes employers who received a positive LMIA but did not hire at least one TFW. Nevertheless, we can crudely estimate that an employer who hired a TFW in 2016/17 had about a one-in-four chance of being inspected, a figure that is extremely high compared to the odds of being inspected in other labour inspection programs, such

\footnotetext{
72 See supra Table 6.

73 See supra Table 1.

74 Employment and Social DeVelopment CANAdA, 2016-Employers Who Were ISSUEd a Positive LABOUR MARKET IMPACT ASSESSMENT (LMIA) IN 2016, BY NATIONAL OCCUPATIONAL CLASSIFICATION (NOC) 2011 AND BUSINESS LOCATION (2016), https://open.canada.ca/data/en/dataset/90fed587-1364-4f33-a9ee$208181 d c 0 b 97$.
} 
as the ESA in Ontario. ${ }^{75}$ This finding suggests that resource limitations are probably not the primary reason for light-touch enforcement in the federal enforcement system.

A more likely explanation is that the government has opted for the compliance model out of choice, not necessity. In a compliance model, it is assumed that most employers are well-intentioned and law abiding and that when they do violate the law it is the result of ignorance or incompetence. Therefore, the primary goal of an enforcement system is to provide compliance assistance, for example, by providing employers with information about their obligations and advice about how to comply. Where non-compliance is detected, it need not be recorded officially so long as the employer agrees to comply in the future and, if necessary, makes restitution to employees who have been adversely affected by the non-compliance. Moreover, even when non-compliance is recorded, deterrence measures like administrative monetary penalties or suspension from the program are be a last resort.

Unless we assume that nearly all employers under the federal inspection program are complying with applicable employment and recruitment laws and are making reasonable efforts to provide abuse-free workplaces (a conclusion that would be at odds with evidence documenting rights shortfalls and exploitation of migrant workers), we must conclude that the inspection system is failing to protect workers against these rights violations in many instances.

Another potential shortcoming of this system is that if employers have their LMIAs revoked, TFWs are at risk of being deported unless they can find another employer who has, or can obtain, an LMIA. There is nothing in the present regulations to provide a remedy for migrant workers in the TFWP who lose their jobs and eventually, their migration status as a result of sanctions against employers. However, one subset of such workers may benefit from a recent regulatory change. As of summer 2019, workers with legal status can obtain open work permits if they can demonstrate that they are "at risk of abuse." ${ }^{\prime 6}$ While in principle this might encourage TFWs to report abuse, given the insecurity of migrant workers and their focus on maximizing their earnings during the limited time they have in the Canadian labour market, as well as the general compliance orientation of the enforcement system, we doubt much will change. In the following section we discuss the policy implications of these results.

\section{Discussion}

The federal enforcement system, makes it a condition of hiring migrant workers that employers comply with basic labour standards and the terms of migrant workers' contracts, as well as requiring employers to make "reasonable efforts" to ensure

\footnotetext{
75 Eric Tucker et al., "Making or Administering Law and Policy: Discretion and Judgement in Employment Standards Enforcement in Ontario" (2016) 31 CAN. J.L. \& SOC'Y 65.

${ }^{76}$ ImMigration, Refugees, ANd Citizenship CANAdA, "Open Work PERMits for Vulnerable Workers" (OTTAWA: IRCC, JUNE 4, 2019), online: https://www.canada.ca/en/immigration-refugees-citizenship/corporate/publicationsmanuals/operational-bulletins-manuals/temporary-residents/foreign-workers/vulnerable-workers.html
} 
workplaces are free of abuse. The system is promising insofar as it seeks to respond to a widely acknowledged rights shortfalls, and integrates labour standards into federal regulatory control of labour migration, but its protective potential of the inspection system is not being reached. A major reason for this is that the government has adopted an extreme version of the compliance model of enforcement in which it is assumed that rights violations are the result of employer ignorance and incompetence. As a result, when violations are detected, penalties rarely follow, provided that employers do not defy the inspectors' authority and make restitution when required. Despite research that challenges the efficacy of this model of enforcement, it is widely used in protective labour law enforcement.

Our data show that employers are rarely cited for non-compliance for violations of migrant workers' workplace rights. The results of inspections, whether paper-based or onsite, confirm that non-compliance with the terms of LMIAs, violations of statutory labour rights and failures to take reasonable measures to prevent abuse are widespread. Despite the fact that nearly half of all inspected employers are noncompliant in the first instance, very few employers are cited for non-compliance and punished. Rather, most non-compliance is excused on the basis of employer justification and payment of compensation where applicable.

The compliance orientation of this new system echoes a long history of enforcement officers in Canadian jurisdictions defaulting to extreme compliance orientations in the absence of strong leadership pushing for a greater use of enforcement powers. ${ }^{77}$ Studies of the enforcement of other statutory labour rights, such as the ESA, contradict the assumptions on which the compliance model is built and thus raise serious concerns about the efficacy of the compliance-based approaches. ${ }^{78}$ Researchers have found that complaint driven enforcement systems are ineffective at identifying and addressing violations, especially if they depend primarily on employee complaints. ${ }^{79}$ This is because workers who experience violations may be reluctant to complain. Complaint-based regimes are particularly unsuitable for vulnerable workers who may not know their rights and, more importantly, may be afraid to exercise their voice due to fear of retaliation, notwithstanding that retaliation is unlawful. ${ }^{80}$ Research has shown that even when migrant workers do not face deportation, they are less willing to complain than their peers. ${ }^{81}$ For TFWs the stakes are even higher, because job loss could result in deportation. ${ }^{82}$ Insofar as this enforcement system is complaint-driven,

\footnotetext{
77 Eric Tucker et al., Making or Administering Law and Policy: Discretion and Judgement in Employment Standards Enforcement in Ontario, 31 CAN. J.L. \& SoC'Y 65 (2016).

78 John Grundy et al., The Enforcement of Ontario's Employment Standards Act: The Impact of Reforms, 43 Can. PuB. Pol'Y 190 (2017); Leah F. Vosko et al., The Compliance Model of Employment Standards Enforcement: An Evidence-based Assessment of its Efficacy in Instances of Wage Theft, 48 INDUS.

RELATIONS J. 256 (2017).

79 D. Weil \& A. Pyles, Why complain? Complaints, Compliance, and the Problem of Enforcement in the U.S. Workplace, 27 COMP. LAB. L. \& POL'Y J. 59, (2006).

80 Vosko, supra note 70.

${ }^{81}$ Barnard, supra note 41 at 241-46.

82 Sarah Marsden, Enforcing Exclusion: Precarious Migrants and the Law in Canada (Vancouver, UBC Press, 2018).
} 
some of the risks may be mitigated if arrangements are made to receive complaints from multiple sources, including members of the public, TFWP stakeholders, foreign diplomatic channels, NGOs, etc.

The extreme compliance orientation of the federal government is exacerbated by its interaction with the primary enforcement of protective labour laws by provincial/territorial governments. Given the well-documented barriers migrant workers face in accessing provincial employment standards remedies, and the fact that such remedies are not always well designed to account for the particular vulnerabilities confronting migrant workers, any effective federal system should respond to these weaknesses. In this regard, however, the federal system also fails. Federal investigators are only authorized to take action after provincial authorities have found non-compliance and so they add no additional resources to the detection of violations. At best, the threat of federal enforcement raises the potential consequences for those caught violating statutory labour rights.

Finally, the current judicial interpretation of the requirement to make reasonable efforts to prevent workplace abuse renders this provision ineffective. In the absence of a finding of actual abuse, it appears almost impossible to hold an employer non-compliant for failing to make reasonable efforts to prevent it. In effect, the "make reasonable efforts" provision does not impose a meaningful duty on employers to take positive proactive measures, but rather provides employers with a due diligence defence in the event abuse occurs.

Arguably the most logical results-driven response to the exploitation of migrant workers is to change the structures of vulnerability that enhance their risk. Replacing employertied, time-limited work permits with open work permits and/or pathways to permanency for migrants providing necessary labour would do much to resolve these issues. Furthermore, migration status security would likely reduce migrant workers' reluctance to use existing rights mechanisms. Failing structural change of this order, our conclusions also support proactive communication between provincial and federal authorities, the use of risk-sensitive selection of employers for inspection which do not rely on complaints, and deterrence, rather than compliance-based policies.

\section{Conclusion}

It is well documented that Canada's TFW program creates structures of vulnerability that produce rights shortfalls for migrant workers. Rather than address those structures, the federal government opted to create an enforcement system to better protect migrant workers from rights violations. As we have documented, the adoption of an extreme compliance model of enforcement, in conjunction with the limited ability of federal inspectors to detect violations of employment laws and the virtual elimination of the employer's proactive duty to take reasonable measures to prevent workplace abuse, have prevented the system from achieving its potential. 